UDK 130.2:165.75:781

Martin Scherzinger

Univerza Princeton, ZDA

Princeton University, USA

\title{
Music in the Thought of Deconstruction / Deconstruction in the Thought of Music (For Joseph Dubiel)
}

\section{Glasba v misli dekonstrukcije ali Dekonstrukcija v muzikologiji (Josephu Dubielu)}

It has been observed, particularly in birds, that the precision of hearing is in direct proportion to the obliqueness of the tympanum. (Jacques Derrida, Margins of Philsophy, xv)

Ključne besede: dekonstrukcija, poststrukturalizem, metafizika, romantizem, Kant, Schopenhauer, Nietzsche, Adorno, Derrida, resonanca, différance, Mebrdeutlichkeit, Mozart, Beethoven, Schubert, Cage, Babbitt, Lachenmann, Andriessen, Ligeti, analiza glasbe, poslušanje

\section{POVZETEK}

Članek kritično pretresa vozlišča podobnosti in različnosti, po eni plati, muzikološke spise in glasbene prakse, ki jih predstavljajo, in, po drugi plati, postopke dekonstrukcije (opredeljene v smislu razlikovalne strukture našega obvladovanja prisotnosti in obilja). Besedilo prinaša dve prominentni napačni razlagi derridajevske dekonstrukcije $\mathrm{v}$ okvir pisanja o glasbi (Subotnik, Korsyn). Sledi kratek opis svojske skladnosti glasbe z Derridajevim modelom jezika argument, ki je razpet nad poljem zgodovine sodobne filozofije (prek Kanta, Schopenhauerja, Nietzscheja, Adorna). Sklepni del članka se ukvarja z vprašanjem, kako se notranji tok glasbenih del (ne) prilegajo dekonstrukciji; proces, ki podaja dekonstrukcijo kot način poslušanja. Primeri vključujejo dela Mozarta, Beethovna, Schuberta, Babbitta, Cagea, Ligetija, Lachenmanna in drugih.
Keywords: Deconstruction, post-structuralism, metaphysics, romanticism, Kant, Schopenhauer, Nietzsche, Adorno, Derrida, resonance, différance, Mebrdeutlichkeit, Mozart, Beethoven, Schubert, Cage, Babbitt, Lachenmann, Andriessen, Ligeti, music analysis, listening

\section{ABSTRACT}

This article critically speculates on points of affinity and difference between, on the one hand, musicological writings and the musical practices they attempt to represent and, on the other, the operation of deconstruction (defined in terms of the differential structure of our grip on presence and plenitude). The article outlines two prominent instances of misreading Derridean deconstruction in the context of musical writing (Subotnik, Korsyn). This is followed by a brief description of music's peculiar resonance with Derrida's model of language; an argument that will be crafted across the terrain of music's modern philosophical history (via Kant, Schopenhauer, Nietzsche, Adorno). The last section of the essay considers how the internal movements of actual musical pieces can (and cannot) articulate with deconstruction; a process that will figure deconstruction as mode of listening. Examples include moments in Mozart, Beethoven, Schubert, Babbitt, Cage, Ligeti, Lachenmann, and others. 


\section{Prelude to an Idealization}

For what is put into question is precisely the quest for a rightful beginning, an absolute point of departure, a principal responsibility. (Derrida 1982: 6)

The musicological reception of the philosophical figure of deconstruction has been belated, paradoxical and short-lived. It is true that silences, contradictions and gaps in musicological discourse (especially those that have been structurally excluded from it) speak more prominently today than they once did, but this general shift rarely registers the precise workings of deconstruction. Instead the shift of attention reflects a general "post-structuralist" turn in America in the late twentieth century, which resonates with the demands of multicultural relativism in a time of changing American demographics. Hence, under the general rubric of deconstruction, we find musicological inquiries that value demonstrations of interpretative pluralism, foreground unique subject positions, critique meta-narratives, and so on. Deconstruction thus tends to be associated with everything from mediation analysis and cultural relativism to epistemological imperfection and contra-normative structures. Without wishing to dismiss the progressive tendencies of such inquiry, this essay will argue that much of the play of deconstruction in musicological parlance is based on a misreading of the term.

Of course, the charge of misreading is foolishly in danger of presupposing the "proper" coordinates of the deconstructive maneuver, as if these can be aprioristically established. In his reflections on the relevance of philosophical limits, Derrida, whose prose is consistently elusive, elliptical and mischievous, warns against the appropriative dimensions of such commitment to le sense propre:

To insist upon thinking its other: its proper other, the proper of its other, an other proper? In thinking it as such, in recognizing it, one misses it. One reappropriates it for oneself, one disposes of it, one misses it, or rather one misses (the) missing (of) it, which, as concerns the other, always amounts to the same (Derrida 1982: xi).

Here Derrida associates "the proper" with both literal correctness and legal ownership, thereby playfully suggesting how, in its attempt to correctly locate its own limits, philosophical thought unknowingly annexes and controls its margins. Beyond the philosophical text, for Derrida, "there is not a blank virgin, empty margin, but another text, a weave of differences of forces without any present center of reference" (Derrida 1982: xxiii). Where Margins of Philosophy concerns itself with opening philosophy to its unguessed-at dimensions ("an inexhaustible reserve, the stereographic activity of an entirely other ear"), my insistence on the proper reading of deconstruction hopes paradoxically to constrain its field of operation (Derrida 1982: xxiii). On the other hand, by launching my inquiry from the vantage point of a narrow, and idealized, understanding of deconstruction, I hope to salvage some specificity for this increasingly vacuous theoretical construct, which in its widespread circulation has come to mean anything from critical overturning to diagnostic analysis.

Deconstruction marks the differential structure of our grip on presence and plenitude. Derrida invents the term différance to capture the peculiarities of this differentiating operation in language. Instead of serving to distinguish/divide an organic unity with stable referents, différance draws attention to the activity producing difference within the sign itself - "the nonfull, non-simple, structured and differentiating origin of differences" (Derrida 1982: 11). The 
incorrectly spelled term différance is precariously suspended between two distinct modes of difference production; that is, différance at once defers and differs. On the one hand, differences are produced by way of a detour or a delay - a mediation that suspends the fulfillment of the conceptual desire for closure. Hence, supplementary criteria, outside of its spatial and temporal immediacy, become basic to the concept under investigation. On the other hand, differences are produced by way of non-identity - an intimate other that haunts the security of the concept. Hence, the opposition engendered by a concept turns out to be more basic to its functioning than either of its poles in themselves.

Consider, for example, Ernesto Laclau's deconstruction of the political concept of toleration: Laclau's analysis begins by stripping away the term's practical contexts and then shuttles between the duality produced by the operation of differing and deferring. ${ }^{1}$ On the one hand, if toleration - to accept practices and beliefs one finds morally disagreeable - is understood as a self-sufficient category without limit, one could logically accept its intimate opposite. Here absolute toleration could paradoxically institute a wholly intolerant society. On the other hand, if toleration is mediated by supplementary criteria - a moral principle that would limit the contradictory emergence of intolerance, say - the term risks becoming meaningless; it risks becoming structurally dependent on terms independent of it. Here unfettered moral criteria could paradoxically parade as toleration. Deconstruction, by marking the contradictory antipodes of a term's logical horizon, opens the possibility of negotiating its antagonistic demands. Deconstruction demonstrates the term's fundamental lack of a necessary content, and thereby reveals its undecidable conditions of possibility and impossibility.

It is in the context of this narrowly idealized construal of deconstruction that this essay critically speculates on points of affinity and difference between musicological writings and the musical practices they attempt to represent, on the one hand, and the operation of deconstruction, on the other. The essay will begin with a description of two prominent instances of misreading Derridean deconstruction in the context of music. This will be followed by a brief description of music's peculiar resonance with Derrida's model of language; an argument that will be crafted across the terrain of music's modern philosophical history. The last section of the essay will briefly consider a sampling of how the internal movements of actual musical pieces can (and cannot) articulate with deconstruction; a process that will figure deconstruction as mode of listening.

\section{Critique}

Whereas ... language arose when the noise produced by the mouth of the lips had become a letter, it is accepted from now on that language exists when noises have been articulated and divided into a series of distinct sounds. (Foucault 1973: 286)

Despite its substantial presence in the humanities at large, deconstruction has only made a scattered appearance in musicological and music theoretical writings in the last two decades. One prominent example of a musicological excursion on the terrain of deconstruction is Rose Rosengard Subotnik's book Deconstructive Variations: Music and Reason in Western Society. Here Subotnik draws on the notion of différance to launch two distinct analyses of Chopin's

See Laclau 1996: 47-67. For a fuller discussion of Laclau's deconstruction and its relation to a certain brand of music theory, see Scherzinger 2004. 
A-Major Prelude. ${ }^{2}$ For Subotnik, deconstruction draws attention to a kind of empirical limit at the heart of all musical interpretation. She emphasizes the perspectival, even subjective, nature of our observations about music, which, for Subotnik, are rooted in a specific historical and cultural context at odds with the music's original context. The strength of deconstruction, in Subotnik's lexicon, is its humbling effect on critics:

Precisely by insisting on the irreducible distance between initial and subsequent meanings, the notion of différance keeps us honest. For while acknowledging limits on what we can know, this notion also precludes us from characterizing as adequate any reading that answers solely to our own personal circumstances. [...] By pushing a conception of 'text' based on différance to the center of criticism, and thereby forcing sensitivity to the problematical aspects of such notions as an 'actual' text, poststructuralist movements such as deconstruction have done a good deal to encourage our integrity as critics. At the very least, these movements have made it more difficult for us to disregard the limiting effects of our own historical and cultural perspective on our access to one another's texts (Subotnik 1996: 56).

Following the post-Kantian idea that epistemological certainty is irreducibly inaccessible (that there exists an uneliminable "gap between our idea and the thing itself"), Subotnik advances deconstruction as a safeguard against the myth of absolute or objective knowledge (Subotnik 1996: 53, 56).

Subotnik associates deconstruction with a particular brand of hermeneutic pluralism. She writes: "Characteristically, a deconstruction results in at least two coherent readings of a single text that coexist but cannot be reconciled with each other. In deconstructionist terminology, the relative weight of these two readings is 'undecidable'." (Subotnik 1996: 66) Far from registering the contradictory poles of a specific concept's logical conditions of (im)possibility, Subotnik's undecidable moment registers the paradoxical coherence of multiple interpretations of a text. Deconstruction, in this argument, serves as a mechanism to ensure that neither interpretation comes to dominate the other: "From this standpoint, all knowledge is ultimately acknowledged as at best a very sophisticated version of fiction, or as a metaphysical metaphor" (Subotnik 1996: 66). Acknowledgement of the epistemological limits of one's own position is thus given pride of place in Subotnik's account. Interestingly, despite the empirical limit inscribed in all musicological inquiry, Subotnik later advances "stylistic listening" - a concept of listening that reckons with music's cultural and historical determinants - as a privileged mode of interpretation. In contrast, "structural listening," defined as "a method which concentrates attention primarily on the formal relationships established over the course of a single composition," is considered ideologically deceptive, for it discounts "metaphorical and affective responses based on cultural association, personal experience, and imaginative play as at best secondary" (Subotnik 1996: 148, 170). Since stylistic listening is favored by the "majority of people," structural listening can become "socially divisive" and "limit the benefits of musical education" (Subotnik 1996: 170). Here Subotnik integrates a commitment to a (demographically-oriented) democratic educational system with a particular methodological orientation.

Without taking exception to Subotnik's set of core principles, which are laudable in my view, the role played by Derrida and other philosophers in constructing the case for democratic relativism is confusing. In 'Toward a Deconstruction of Structural Listening' the problem

See Rose Subotnik 1996. For a fuller, and slightly differently nuanced, examination of the limits of Subotnik's argument, see Scherzinger 2004. 
begins with Subotnik's use of Nietzsche to question the supremacy of "structural listening" in educational systems in America. Subotnik writes,

it has become easy to 'forget,' in Nietzsche's sense, that the object of structural listening, a structure that is in some respect abstract, constitutes only one pole of a more general, dialectical framework in which modern Western conceptions of music have been developed (emphasis mine, Subotnik 1996: 148-149).

While it is true that a limited brand of music analysis became established as a norm in centers of advanced study in the U.S. through the course of the twentieth century, how does Nietzsche's sense of forgetting function in this observation? In an early essay, Nietzsche ironizes the impulse to truth by insisting on a generalized experience of the impossible:

What indeed does man know about himself? [...] Does not nature keep secret from him most things, even about his body [...] so as to banish and lock him up in proud delusive knowledge? Nature threw away the keys [...] and [...] man, indifferent to his own ignorance, is [...] hanging in dreams on the back of a tiger (in Derrida 1976: xxv).

Similarly, in Gay Science, Nietzsche argues that man's truths are no more than man's irrefutable errors (Nietzsche 1974: 39-174). For Nietzsche, these errors are not easily corrected or revised because they constitute the very possibility of life.

Thus Nietzsche's discussion of "forgetfulness" is double-edged: On the one hand, forgetfulness shields humanity from the insight that "truths" reside in the operations of habit and convention, but on the other hand, forgetfulness opens up the affirmative act of choosing to suspend this insight in service of social or cultural advancement. In On the Genealogy of Morals, Nietzsche writes:

Forgetting is no mere vis inertia as the superficial imagine; it is rather an active and in the strictest sense positive faculty of reason [Hemmungsvermögen]. [...] To close doors and windows of consciousness for a time; [...] to make room for new things, [...] so that it will be immediately obvious how there could be no happiness, no cheerfulness, no hope, no pride, no present, without forgetfulness. (Nietzsche 1989: 57).

Productive forgetting, in the Nietzschian sense, is a warning against the impulse to "situate," "contextualize," and "historicize" knowledge. In On the Advantage and Disadvantage of History for Life, Nietzsche claims that

the historical sense makes its servants passive and retrospective; and almost only from momentary forgetfulness, at a brief period of inactivity of that sense, does the man struck ill by historical fever become active (Nietzsche 1980: 45).

Forgetting therefore involves an actively repressed "will to ignorance" that paradoxically creates a provisional space for social action. For Nietzsche, "action requires illusion" (Nietzsche 1967: 60). Within the deliberately framed "forgetfulness," the critic is able to advance a polemic without lapsing into generalized doubt or relativism. With this provocative and strategic sense of forgetting in mind, Subotnik's "structural listening" could become a site of active repression that makes possible a certain kind of social action. However, Subotnik does not examine the 
active figure of forgetting, emphasizing instead a passive view, whereby our memory lapse is a case of neglect. We have neglected to attend to other modes of listening, forgotten the importance of "stylistic listening".

This problem is analogous to Subotnik's later attempt to "deconstruct" the notion of "structural listening". She writes,

Recognizing a hierarchical opposition between structure and medium as fundamental to the concept of structural listening, I have in effect tried to reverse the conventionally assumed priorities in this hierarchy, to undercut the distinction between the poles by presenting the mode and object of structural listening as a function of (or in Derrida's sense as a 'supplement' to) those of non-structural listening, and to expose some of the concealed ideological assumptions which the concept of structural listening reflects (Subotnik 1996: 149).

Once again, without dismissing the undoubted value of Subotnik's critique of structural listening, it is a curiosity that structural listening is placed here in supplement to non-structural listening. In Derrida's terms, this, in effect, claims that "structural listening" is the subordinate term marking the inadequacy of, yet paradoxically making whole, the sign "non-structural listening". In other words, the asymmetry in this opposition is the converse of the asymmetry narrated in the argument as a whole. According to Derrida, an opposition is rendered non-pertinent when différance intervenes, because, for the former term to be truly itself, the supplement becomes an essential condition. ${ }^{3}$. Thus, transposed to Subotnik's argument, for "non-structural listening" to be truly itself "structural listening" is an essential condition. But this amounts to the unwanted deconstruction of non-structural listening.

Subotnik uses the term "supplement" again in a way that does little to allay this unintended consequence. "For Adorno," she writes "...metaphorical criticism of the characteristics, choices, and relationships that embed music in one or another socio-historical context is not a 'supplement,' in Derrida's sense, to the possession of detailed structural knowledge but rather the very means of getting to the heart of such knowledge" (Subotnik 1996: 165). I take this to be a negation of the following scenario: A "contextually sensitive" knowledge (to use a shorthand for Adorno's "metaphorical criticism") is a supplement to "structural" knowledge. This means that the hierarchy presented by the scenario is false. Instead, (the truth is that) the "contextually sensitive" knowledge "get[s] to the heart of such knowledge". Has the principal deconstructive maneuver been missed here? By marking the supplementary term, différance reveals the differential undecidability of our hold on the primary term. In this way, the supplement has the negative privilege of illuminating the exclusion that has defined the metaphysical) enclosure of the concept under scrutiny. In a deconstructive setting the supplementary term is not ostracized but affirmed as central to that enclosure. Subotnik's supplement, in contrast, has no such affirmative privilege. The supplementary term in her scheme is absolutely subordinate; it inhabits what Derrida might call "a place of death and disease in general". In contrast, the primary term ("contextually sensitive" knowledge) "is not a supplement," but "the very means of getting to the heart" of knowledge (italics mine, Subotnik 1996: 165). But the supplement, construed as entirely subordinate, produces an unnecessarily hierarchical opposition between the two modes of hearing. It does not undercut as much as reverse a prevalent historical opposition.

Subotnik's challenge to the discipline is also a commitment to an actual state of social affairs - a final resting place, as it were, for truth - that appears as an underlying motif throughout

3 For Derrida's account of the workings of the supplement, see Derrida 1976: 141-164; and for his account of différance see Derrida 1982: 127. 
her book (under rhetorical signs like "in actuality" (Subotnik 1996: 157, 169), "in fact" (158), "originating norms" (163), "the heart of" (165), "conclusively" (168), "source" (169), "rests finally" (170), "at bottom" (172), "in its original sense" (169), and so on). I will comment on the last of these gestures. Subotnik writes, "Ever since the crystallization of the notion of 'Art' in the early nineteenth century, it has become a truism of Western culture that the proper evaluation of any structure as 'Art' requires the perspective of time" (168). In this section of the argument, Subotnik claims that "insiders access" to an artist's meaning becomes impossible with a time lapse, because such an access demands, by implication, that the interpreter "understand the full import of those changes [or meanings] at the time they were made" (168). Drawing on Derrida, Subotnik inserts the formula "always already" to emphasize this impossibility. In other words, when time passes we inevitably lose the original (authentic?) meaning of an artwork.

But Derrida's "always already" marks the irreducibility of the supplement (fissure, accident, accessory, spacing, etc.) within the origin of the structure of knowledge itself. In his critique of Rousseau's writings on speech and song, for example, Derrida comments on the "always already" (Derrida 1976: 200-201): First, this is not about the loss of the "full import" of meaning because of a "time lapse" but about a fissure (supplement) that has been "inscribed [...] from its birth and in its essence" (italics mine, Derrida 1976: 200-201). Likewise, in his essay "Différance," Derrida writes, "Différance is the non-full, non-simple, structured and differentiating origin of differences" (italics mine, Derrida 1982: 11). Second, and perhaps more important, the fissure/supplement is that accessory "without which, strictly speaking, the [structure] would not have come into being" (Derrida 1976: 200). In short, the fissure is an "originary accessory" or "essential accident" that inaugurates the possibility of thought.

In contrast, Subotnik version of the "always already" makes us notice the impossibility of thought. This is a misreading of deconstruction, and leads to the odd conclusion that "this condition of difference and delay, which Derrida has termed différance, calls increasing attention over time and distance to the irreducibility of style [...] as a source of signification" (Subotnik 1996: 169). Besides the fact that Derrida is less concerned with proliferating such differences than he is with disconcerting certain regularities, Subotnik here locates "style" at the "source" of signification. This momentary construction of a "source" cannot be accommodated in the terms of a thoroughly deconstructive argument. Furthermore, there is another (more embedded) "source" that has been axiomatically posited in the argument. This "source" is the "truth" that has been lost during the "time lapse". This is the not-spoken-about "original sense" that must exist, albeit as absence, to make possible the impossibility of a full understanding. Subotnik insists that "invoking our own cultural disposition [...] after a certain time-lapse is no proof of an acquired ability to hear musical structure in its original sense" (Subotnik 1996: 169). The "source" I mark here is the "original sense" that we can never "prove". ${ }^{4}$ This is an ultimate source, figured as absence, which gives all interpretation the slip: "If anything," the argument goes, "we remain excluded as interpreters from the original inner dynamic of most music" (Subotnik 1996: 169). Forever "outside" of this source, or "fallen" from the original truth, our "reading itself becomes an inconceivable act" (Subotnik 1996: 169). It is possible to contest this reading of Derrida by reciting the latter's resistance to French psychoanalyst Jacques Lacan's transcendental signifier. More pressingly, however, how do we now gauge Subotnik's appraisal of "stylistic listening" in this argument?

Having outlined a state of affairs in which any assertion is but a simulacrum of an original truth, it is difficult to grasp this appraisal: "Only something akin to 'stylistic listening' would

This is a kind of signifier (signifying all knowledge as absence) that takes the place of all signifiers; a transcendental signifier in the order of Jacques Lacan's phallus, or Edgar Allan Poe's letter in his Purloined Letter. 
permit contemporary listeners to exercise any prerogatives they might have as cultural insiders" (Subotnik 1996: 170). The problem is that "stylistic listening" gets closer to that "original significance" that, scarcely three paragraphs before, had been described as inherently "unrecoverable," "always already impossible," an "inconceivable act" (Subotnik 1996: 168-9). There are neither reasons advanced as to why any reading becomes suddenly possible/recover able/conceivable, nor why such a (now recoverable) reading is necessarily, and only, a "stylistic" one. Besides the point that the only listening that is being "discounted" is "structural," one is forced to conclude that "stylistic listening" gains its credibility by virtue of its privileged access to the "original inner dynamic" - replete with historical, cultural, stylistic resonance - of the music under investigation (Subotnik 1996: 169). Subotnik is implying here that "stylistic listening" gives us access to the reality of music, an argument that ultimately has the effect of bestowing a preferred mode of hearing with epistemological authenticity. The point is that deconstruction cannot be claimed to have produced this kind of priority. Without rejecting the many virtues of its particular positions and insights, I hope to have shown that Subotnik's Deconstructive Variations is not, in the final analysis, properly deconstructive.

Deconstruction has appeared in music-theoretical writings as well. One exemplary text is Kevin Korsyn's Decentering Music: A Critique of Contemporary Musical Research (Korsyn 2003), which sets out to alter the very coordinates of what goes as musical scholarship in our times. The book has transformative ambitions; in Korsyn's words, it is a book that "seeks to change musical scholarship by addressing a crisis confronting us today." The crisis, argues Korsyn, is grounded in "discourse," understood here in the Lacanian sense as "a social link [lien social] founded on language." (Korsyn 2003: 5) Because language, under recent French philosophical lights, is prior to individual utterance and expression, it always exceeds (and escapes) our grasp. Korsyn argues that the practice of music scholarship is likewise bound up in socio-cultural forces that lie beyond its immediate control. Korsyn's book includes discussion of programmatic constraints on musical discourse no less than institutional rigidities, right down to the nitty-gritty of the tenure process and the dynamics of program committee selection.

He diagnoses a symptomatic dialectical impasse. On the one hand, the splintering of scholarly dialogue into specialized branches of study ("crisscrossed by [...] antagonisms, which divide the field into ever smaller units") has produced a kind of "radical disengagement" between factions of a discipline, which nonetheless bears the marks of hierarchicallyimposed exclusions (Korsyn 2003: 6, 15). In short, musical research, under current professional pressures, is becoming a hierarchized "Tower of Babel" (Korsyn 2003: 16). As remedy, Korsyn aims to retrieve and engage the marginal and excluded domains that ground the very possibility of the discipline (Korsyn 2003: 16). On the other hand, the very "corporatist" model that divides scholarship into sub-disciplines simultaneously mandates "increasing uniformity" within these disciplines (Korsyn 2003: 6, 26). Korsyn isolates key features of scholarly standardization vis a vis the commodity form: abstraction, efficiency, quantification (Korsyn 2003: 20-25). Here he draws a tantalizing link between the "ideology of the abstract," which issues the professional "tendency toward uniformity," and the broader economic sphere of Fordist economics, which governs the way the university operates (Korsyn 2003: 24-25, 182). In short, music research, under current professional pressures, is becoming an Orwellian "Ministry of Truth" (Korsyn 2003: 25). As remedy, Korsyn aims to imagine new forms of musical community no less than to restructure the university system. Ultimately, he seeks scholarly heterogeneity without lapsing into Babel-esque relativism or imposing Ministry-esque consensus. 
For all its wealth of insight, Korsyn's use of deconstruction to support his argument is limited. In "The Objects of Musical Research (I)," for example, Korsyn uses Derrida as a guiding figure in theorizing his argument about compositional identity (Korsyn 2003: 91-100). With incomplete success, Korsyn tries to bend Derrida's analysis of our uncertain hold on self-presence to the identity of musical phenomena. In particular, Korsyn takes his cue from Derrida's notion of iterability to discuss musical repetition. Korsyn quotes Derrida - "the presence-of-thepresent is derived from repetition and not the reverse" - and correctly notes that the sign depends on a kind of "originary repetition" (Korsyn 2003: 93). But the translation of Derrida's philosophical values into his music analyses is weak, incongruous even. For example, Korsyn discusses musical repetition in the context of traditional ideas about phrase rhythm in a work by Mozart. The Piano Sonata, K. 283, opens with an expansion of the first ten measures via near-repetition of $\mathrm{mm}$. 5-10 in mm. 11-16. For Korsyn this is a case of "originary repetition" because, instead of following one another consecutively in time, "repetition and expansion appear together" (Korsyn 2003: 93). Moreover, argues Korsyn (following William E. Caplin), the ten-bar prototype of this expansion is itself an expansion of an "eight-bar norm," figured as an "absent prototype" (Korsyn 2003: 95). Likewise, Korsyn interprets Chopin's B Minor Prelude as "an expanded repetition of itself: it is an expansion of a sixteen-bar prototype that is nowhere given." Korsyn continues, "To establish the identity of this piece once and for all it would be necessary to say here is the original, there is the expansion, establishing a hierarchy between the two. Instead, however, the piece exemplifies what Derrida calls différance: it differs from itself - its identity is deferred. It is precisely because the identity of the piece is uncertain that we need analysis" (Korsyn 2003: 96).

This is an odd argument, for Korsyn collapses general and particular levels; namely, the workings of "repetition" between pieces and "repetition" within a piece. The absent norm he identifies in K. 283 hinges on the idea that "nothing precedes it that might constitute a prototype" (Korsyn 2003: 95). This claim is overdrawn. "Norms," whether they describe average sizes of modern American families or lengths of classical musical phrases, are "absent" only in a limited, literalistic, sense; they are the result of empirically-oriented experience seeking to grasp the general characteristics of things. (In scientific empiricism this can involve the use of surveys and statistics). For Derrida, the irreducible undecidability of differance is not the result of some empirical imperfection, but rather a trace of contingency lodged within the logic of any structure (at its origin). Likewise, the "phantom existence" of the eight-bar prototype in Chopin's Prelude shares no kinship with Derrida's "absence" prior to the sign's repetition. Derrida is not addressing the absence of some kind of abstract plenitude (like "2.3 children" per household, for example, or "eight measure units" of music), which guides the signification process. On the contrary, différance marks the differential structure of our grasp on presence and plenitude. Far from marking the sign's normative background, the operations of différance foreground its irreconcilable dialectical extremes. In the deconstructive analysis there is no doubt about the sign's ordinary meaning; indeed, the movement of deconstruction illuminates the conditions of possibility and impossibility in which such ordinary meaning is instituted. In Korsyn's analyses, in contrast, the "identity of the piece is uncertain;" indeed the uncertainty prompts the "need [for] analysis" (Korsyn 2003: 96). In sum, where the deconstructive account renders undecidable the certainty of the sign, Korsyn's account clarifies the uncertainty of the music's identity.

This is not to say that Korsyn's broad argument is not plausible; but that the figure of deconstruction is employed in a limited way in this text. Nor is this to say that Derridean deconstruction, which establishes language (speech, writing, etc.) as its central referent, is out 
of place in the context of sounding music and thought about music. Although it is not the thrust of Korsyn's argument, it is possible, for instance, to configure music as a performative dramatization of Derrida's theory of language formation; an idea that resonates with music's privileged position in Continental philosophy of the nineteenth and twentieth centuries.

\section{Music in the Thought of Deconstruction}

Music is the diachronic version of the pattern of non-coincidence within the moment. (Jean-Jacques Rousseau, in: Man 1983: 129)

Derrida writes:

It is because of différance that the movement of signification is possible only if each so-called "present" element, each element appearing on the scene of presence, is related to something other than itself, thereby keeping within itself the mark of the past element, and already letting itself be vitiated by the mark of its relation to the future element, this trace being related no less to what is called the future than to what is called the past, and constituting what is called the present by means of this very relation to what it is not: what it absolutely is not, not even a past or a future as a modified present. (Derrida 1982, 13)

This description of language is strikingly musical. Instead of emphasizing its referential specificity, Derrida draws attention to the play of differences inscribed in language. As it is with music, linguistic signification is irreducibly temporal, caught up in a network of "retentional traces and protentional openings" that make possible the sign that is said to represent the thing itself. In a general way one may surmise that music - the art that prominently foregrounds a kind of "playing movement that 'produces' [...] differences, [...] effects of differences" - dramatizes Derrida's model of language.

Do the endlessly suspended melodies of Wagner's Tristan, achieved by way of hyperbolic appoggiaturas that chromatically slide toward cadential non-closure, not différer in Derrida's sense? Do they not take recourse, that is, "in the temporal and temporizing mediation of a detour that suspends the accomplishment of fulfillment of 'desire' or 'will'" (Derrida 1982: 8)? Does Brahms's uncanny invocation of Beethoven's Ode in the last movement of his first symphony, an invocation that comes out of the workings of his own developing variations, not destabilize the thing for which it ostensibly stands? Is the reference, that is, not like a mirage, "constituted 'historically' as a weave of differences" (Derrida 1982: 12)? Do the misplaced perfect cadences in the last movement of Mahler's seventh symphony not radically open the contextual horizon of their musical function? Does the familiar but flawed cadence, that is, not sound like "the mute irony, the inaudible misplacement" of Derrida's misspelled différance (Derrida: 1982: 3)? At this level of generality, the list of resemblances between deconstruction and music goes on and on.

It should not be surprising that Derrida's deconstructive excursions are historically linked to a philosophical tradition that grants the figure of music pride of place. Music, in this tradition, was figured as ineffable, beyond the logic and grasp of representational language. In the shad- 
ow of an imagined failure of language, music was often granted the capacity for elevated epistemological claims qua music. Already in Kant, whose views about it were otherwise outmoded, music had the capacity to "agitate the mind more diversely and intensely" than poetry, which, for Kant, was the highest form of the arts (italics mine, Kant 1951: 198). While unable to conceptualize, and hence lacking the capacity to expand the power of judgment, music was nonetheless able to express "the aesthetic idea of a coherent whole of an unspeakable wealth of thought, and to express it in conformity with a certain theme that is the prevalent affect in the piece" (Kant 1951: 199). Concepts, for Kant, could be raised to the level of ideas when they transcended their "natural determination" by way of the imagination (Kant 1951: 196). Poetry, which shared with music the ability to "set the imagination free," could offer us "from among the unlimited variety of possible forms that harmonize with a given concept, though within that concept's limits, that form which links the exhibition of the concept with a wealth of thought to which no linguistic expression is completely adequate, and so poetry rises aesthetically to ideas" (Kant 1951: 196). Interestingly, to rise aesthetically to ideas, concepts had to be illuminated by the very "unspeakable wealth of thought" that characterized both poetry and (even more so) music. What distinguished poetry from music in Kant's comparison was poetry's capacity to harmonize its "unspeakable wealth of thought" within the limits of a given concept. While exhibiting the imaginative play so crucial to idea formation, music's refusal to be reined in by determinate thought rendered it secondary in Kant's evaluation; "mere entertaining play;" patterned air (Kant 1951: 197). And yet, Kant's recognition of music's unbounded wealth of thought opened the door to a radical revision in the nineteenth century of music's metaphysical aspirations.

It was precisely music's unspeakable wealth, detached from all conceptual determination, which became its greatest advantage in the imaginary of nineteenth-century metaphysics. This idealization of music took many forms. For Wilhelm Heinrich Wackenroder, for example, music hovered angelically above the debased workings of the actual world. Likewise, for Søren Kierkegaard, music best exemplified the boundless erotic striving of the pure unmediated life force. Arguably, the quasi-religious appeal to notions of genius and inspiration in the age of romanticism were an attempt to detach the art of music from the realm of ordinary signification. August Wilhelm von Schlegel's account of the "origin and spirit of romanticism" rested on a religious dimension that "aspired to a higher perfection than that which could actually be achieved by the exercise of [one's] own faculties" (italics Schlegel's, in: Huray / Day1988: 196198). Romantic art required the intervention of a "superior wisdom" if it was to transcend the limited perfection which Schlegel attributed to the art of the ancient Greeks and offer us instead (via "contemplation of the eternal") insight into "our real existence" (Huray / Day 1988: 198). For Gottfried Johann Herder too, the defining moment in the emancipation of music from outside constraint (from "spectacle, dance, mime, and even from the accompanying voice") was "religious awe" - a condition best approximated by voiceless, gesture-free, wordless and pure "sounds." (italics Herder's, Huray / Day 1988: 192). Far from a condition of self-identical autonomy then, the artwork required this extra "something [to] free [it] from all external control" (italics mine, Huray / Day 1988: 192).

Paradoxically, the exemplary romantic artwork was thus incomplete in itself, even giving an "appearance of imperfection" in Schlegel's language, and the necessary supplemental dimension (or "mysterious alliance") could not be captured in ordinary terms (Huray / Day 1988:198). In short, the aesthetics of autonomy were deeply implicated in a new principle of anagogic transformation on the levels of both composition and reception, and it was music's apparent insufficiency that secured its autonomy. Even in Eduard Hanslick's late nineteenthcentury formalist aesthetics, apparently shorn of religious dimensions, we read about the meta- 
physical and symbolic significance of music in its "reflection of the great laws of the world." (Bond 1997: 415) Interestingly, references of this sort were omitted in subsequent editions of Vom Musikalisch-Schönen, so that Hanslick's later musical work began to exist in an abstract realm of self-sufficient signification. But the logic of the argument - the effort to avoid music's reduction to ordinary referential terms - remained the same.

How did the metaphysical elevation of music in the nineteenth century function philosophically? In his The World as Will and Representation Arthur Schopenhauer posits music as the closest of all possible analogies to the endlessly striving will. Far from figuring music's inability to conceptualize as a weakness, Schopenhauer diminished the very role of conceptformation to the "objectification" of the will, and thereby raised the value of music's peculiarly independent expressive mode to new metaphysical heights. By granting the will a foundational metaphysical status, Schopenhauer shifted the traditional theory of truth-by-correspondence to one of truth-by-revelation, best embodied in the flow of music. In Schopenhauer's view, "music does not, like all the other arts, exhibit the Ideas or grades of the will's objectification, but directly the will itself" (italics in original; Schopenhauer 1958: 448). Music's very separation from the world of representation elevated its self-generative power to disclose truth: "Far from being a mere aid to poetry, music is certainly an independent art; in fact, it is the most powerful of all the arts, and therefore attains its ends entirely from its own resources" (Schopenhauer 1958: 448). Even in the context of texted compositions (where "words are and remain for the music a foreign extra of secondary value"), music had the capacity to express "the most profound, ultimate, and secret information;" it illuminated "the real and true nature" of the feelings and actions presented by the musical drama. Music, in the final analysis, had privileged access to the fundamental truth of our lives, for in its temporal unfolding one could "hear [...] the secret history of our will and of all its stirrings and strivings with their many different delays, postponements, hindrances, and afflictions" (Schopenhauer 1958: 451). Shopenhauer degraded the referential abstractions that characterized language and prized instead the "delays and postponements" that characterized music. It was music's endless deferrals that became portals for understanding our essential nature.

In his early works, Friedrich Nietzsche too would subordinate the epistemological status of language against that of music. The concepts of language are "the separated shell of things; thus they are strictly speaking abstracta;" in contrast, music "gives the innermost kernel which precedes all forms, or the heart of things" (Nietzsche 1967: 102). For Nietzsche, language is reductive and abstract, while music is generative and creative. Hence, language cannot capture the spirit of music: "Language can never adequately render the cosmic symbolism of music, because music stands in symbolic relation to the primordial contradiction and primordial pain in the heart of the primal unity, and therefore symbolizes a sphere which is beyond and prior to all phenomena" (Nietzsche 1967: 55). In agreement with Schopenhauer, then, Nietzsche argued that words rendered musically, and even feelings expressed in music, were distracting "externalities" to music's essence:

What we call feeling is, in relation to th[e] will, already permeated and saturated by conscious and unconscious representations and hence no longer directly the subject of music (Nietzsche 1967: 111, 112).

On the Ode in Beethoven's ninth symphony, Nietzsche polemically claimed that the

music blinds us totally to images and words and we simply do not hear anything of Schiller's poem (italics in orginal; Nietzsche 1980a: 113). 
Against Schopenhauer, on the other hand, Nietzsche was suspicious of our ability to access, even by way of musical analogy, the workings of the will. And yet, although we "can never get beyond representations," Nietzsche distinguished "two major species in the realm of representations," one of which recapitulates the will's primordial "becoming and willing" (Nietzsche 1980: 108). On this species of representation, Nietzsche wrote, "The primordial manifestation, the 'will' with its scale of sensations of pleasure and displeasure, gains an ever more adequate symbolical expression in the development of music" (Nietzsche 1980: 109). For the early Nietzsche, then, music's origin remained "beyond all individuation;" and the will remained music's proper "subject" (Nietzsche 1980: 110-111).

It was music's non-individuated Dionysian strain, representing the rapturous frenzy that destroyed the veils of maya, and thus liberated us from conventions, images, rules and constraints, which Nietzsche granted profound philosophical agency in his The Birth of Tragedy in the Spirit of Music. Music's "most powerful" function lay in its capacity to "invest myths with a new and profound significance," for it prevented myths from lapsing by degrees "into the narrow limits of some alleged historical reality" (Nietzsche 1980: 75). Music's ability to disclose truths was thus achieved in negative terms. It revitalized myth by inhibiting its historical tendencies toward ossified factuality. Following the example of Socrates, philosophy had long neglected music's creative impulse in favor of a rationalist dialectic. Just as music once gave "birth to myth" it could once again revitalize it:

Th[e] dying myth was now seized by the new-born genius of Dionysian music; and in the hands it flourished once more with colors such as it had never yet displayed, with a fragrance that awakened a longing anticipation of a metaphysical world (Nietzsche 1980: 103, 75).

By musicalizing philosophy, Nietzsche sought to reinvigorate its creative and critical potential. Music illuminated the mythical dimension of the orthodoxies by which we lived; it served as a discursive site for speculation on the limits of philosophy, knowledge, and meaning. A central metaphor for that which resisted epistemological certainty, music in this kind of philosophical discourse thus functioned as a kind of discourse of the unsayable par excellence.

The negative privilege accorded music in nineteenth-century German metaphysics is no longer obvious in current writings grounded in philosophical tropes of negation. While some German philosophy in the first half of the century, ranging from Ernst Bloch's reflections on music, which emphasized the open-ended and refractory qualities in music, to Theodor W. Adorno negative dialectics, which prominently explore the role of truth-formation (via relentless self-abnegation) in musical experience, the explicit reference to music has receded in most post-structuralism. And yet, post-structuralism bears some prominent resonances with these predecessors. As it is with nineteenth-century philosophical figure of music, deconstruction, for example, exposes the slippery movement of conceptualization, and menaces the poles of ossified historical oppositions. Deconstruction, like music, marks a philosophical limit. Following Hegel's dialectical method of marking the non-identities grounding all conceptualization, the deconstructive account emphasizes the structural irreducibility of that which is excluded from discourse. Like Schopenhauer's music, for example, deconstruction emphasizes the detours and delays that condition the world of representation. And like Nietzsche's music, for example, deconstruction at once resists the closure of ordinary discourse and revitalizes its horizon of possibility. Music's resistance to the grasp of self-evident perception dramatizes what deconstruction sets out to demonstrate. 
Though it has generally been canceled out of post-structuralist thought, music sometimes reappears in a way that is in keeping with this historical legacy. Roland Barthes's discussion of the "grain" in the operatic voice, for example, draws on the historical idea that music - its visceral materiality - escapes the scope and authority of predicative language (Barthes 1985: 26777). Likewise, Julia Kristeva's non-representational theory of language is distinctly musical; here the "tone" and the "rhythm" of the pure signifier reverberates as if in musical space (in Eagleton 1983: 188). Derrida too elaborates the already-discussed notion of the supplement, which marks the absent, yet necessary, term constituting the possibility of conceptualization, through an investigation of Jean Jacques Rousseau's discussion of melody in the Essai sur l'origine de langue (Derrida 1976: 141-64). And yet, these references to music are rarely about music itself. They are about a theory of language-as-music. To maneuver somewhat crudely through the historical genealogy, one might say that Schopenhauer vividly divided the (debased) world of abstract language from the (elevated) world of dynamic music; that Nietzsche drew this distinction into the workings of language itself (reconfigured in terms of its Dionysian and Apollonian tendencies); and that Derrida collapsed these modalities of representation altogether, effectively drawing musical dynamism into the nature of language as a general economy.

Nonetheless, discussion of actual music in Derrida's considerable oevre is conspicuous by its absence. On the one hand, Derrida frequently laments his personal lack of competence when it comes to the subject of music. On the other hand, he describes his philosophical aspirations in overtly musical terms. For Derrida, close attention to the inherent multiplicity of "voices" in a text is linked to an ethics of empathy with the other. This is an empathy less borne of identification than interruption; an ethics of opening to the unanticipated threads at work in a text, which in turn liberates its full resonance.

There is first of all the plurality of voices as plurivocity - Mebrdeutigkeit.

Already when a word has several meanings - and this plurality is irreducible - you can hear in it, or it lets you hear ..., several meanings and thus several voices. There are several voices already in the word. One can give this plurality of voices in the word itself its freedom, more or less freedom. There is another experience that consists in organizing a text in such a way that several voices take it over. (Derrida 1995: 393)

Here Derrida attempts to withstand the appropriative closures inherent to all reading/listening by offering a writing strategy that, to unleash a free play, advances "in several voices". As a safeguard against mastery the writing is thus led away from its own suppositions and toward the radically unassured:

One is not sure of one's direction precisely because it is the other who is leading the march or the discourse. To walk on one's own head [Derrida borrows the phrase from Paul Celan] means of course to look at the sky ["as an abyss," in Celan's terminology], but also to walk upside down, to do the opposite of what one thought one wanted to do. And to lose one's voice or let the other speak is always in a certain way to walk on one's head (Derrida 1995: 393).

Derrida describes this art of "walking on one's head" - like a "madness" that keeps "watch over thinking" - in terms of musical resonance (Derrida 1995: 363, 394). It is not so much a matter of writing "about ... the multiplicity of musical voices" in a text as it is about letting its music resonate (italics in original; Derrida 1995: 394). 
And yet, in Derrida's lexicon, musical resonance cannot be adequately facilitated by ordinary prose. Following Nietzsche on this point, Derrida associates the origin of philosophy with the death of music:

But I wonder if philosophy, which is also the birth of prose, has not meant the repression of music or song. Philosophy cannot, as such, let the song resonate in some way (Derrida 1995: 394).

In spite of this necessary failure, his aim, nonetheless, is to let

the multiplicity of voices in music [...] take over - and keep - speech through me, without me, beyond the control that I could have over them. [...] I try to let them speak (Derrida 1995: 394).

For Derrida, the polyvalence of a text is here associated with the art of musical listening an act of allowing the already-present threads distributed in the text to appear, and link up, in unforeseen ways. While absent as a direct object of Derrida's philosophical inquiries, music therefore metaphorically embodies the art of suspending the assurance of referential self-presence. It is music's many-voiced resonance that resists the saturating taxonomy of its themes in ordinary prose. The point is to listen.

\section{Deconstruction in the Thought of Music}

The tympanum squints. (Derrida 1982: xv)

Does music itself issue forth deconstructive resonance? Not always. The weakness in Derrida's metaphorical figure of music is its lack of specificity. At first glance, it seems, we may speak of resonance as characteristic of a sounding tone in general. Paraphrasing Derrida, that is, there are "several voices already" in the tone itself. The musical consequences of this resonance have been pondered for centuries (from Pythagoras to Joseph Sauveur to Arnold Schoenberg). While I cannot take up this lengthy history here, it is worth noting that current schools of compositional thought, such as the French school of "spectral music," for example, have congealed around creative attempts to unleash, in all its unheard complexity, this pregiven resonance - an unleashing which, in turn, has menaced the traditional distinctions between harmony and timbre and even harmony and rhythm. And yet, to talk about the compositional systems that derive from the rigorous formalizations guiding spectral analysis of acoustic phenomena as a case of deconstructive resonance is in error. More likely, the spectral approach is deconstruction in reverse. Far from opening into the radically unstable experience of resonance issued by a particular musical tone, spectral music is premised on an alreadysecure general theory of both the acoustic tone and its cognitive perception. The tone, as it were, is already an inmate of this theoretical logic, it is already ontologically secured; and the individual composition is no more than a proof of the ontology. ${ }^{5}$ In Derrida's terms, one might

The following passage in defense of the spectral school of composition is typical: "The tonal system is governed by a set of harmonic rules that embody a compromise between the will to modulate among keys, the system of symbolically notating music, the available set of instruments, certain laws of acoustics, as well as many other concerns. This imposing edifice was patiently constructed by an accumulation of experience and benefited from a slow, cultural maturation. But the bases of this edifice were shaken in the evolution of contemporary music by recent developments in our relation to sound: previously of a fleeting and evanescent, ungraspable nature, sound has been captured and manipulated by way of recording technology. The theory of signals, associated with the computational power of modern computers, has made it possible to analyze sound, to understand its fine structure, and to fashion it at will" (see Pressnitzer / McAdams 2005). 
say, the "strange and unique" properties of the music's resonance is secured by the "discourse that organizes the economy of its representation, the law of its proper weave, such that its outside is never its outside, never surprises it, such that the logic of its heteronomy still reasons from within the vault of its autism" (Derrida 1982: xvi). Of course it is possible to deconstruct the logic of this compositional endeavor, or even to unhinge the center of the implied perceptual field; but it is not possible to attribute to this figure of musical resonance per se a deconstructive ambition. As such, its heteronomy has been "spatialized" into a general economy of the same; the horizon of what is hearable has been pre-planned. The ethics of tonal resonances, one might say, are not equal.

How, then, can music behave deconstructively? Can musical resonance open into internally differentiated temporalities that are not ambushed by the general strategies of hearing meant to explain them? Here, at first glance, it seems that the serial music of the post-Schoenberg school, with its irreducibly polysemic permutational networks which necessarily annul the self-present perception of its resonating tones, becomes a musical site of deconstruction. In Milton Babbitt's paradigm, for example, "all-combinatorial" twelve-tone sets (whereby complementary hexachords are produced under all operational transformations of the set) open music into a vast network of connections reducible to no self-evident musical sense. As it was for Schoenberg, the ordering of the row is a crucial springboard for reflecting inner motivic resemblances no less than subtle mutations. Babbitt writes, "I want a piece of music literally to be as much as possible". In Babbitt's view, the modern composer has been "obliged to recognize the possibility, and actuality, of alternatives to what were once regarded as musical absolutes. He lives no longer in a unitary musical universe of 'common practice,' but [rather] a variety of universes of diverse practice". Only when this general compositional multiplicity is congealed into the very workings of a particular piece can music open into "as much as possible" (Babbitt 1978: 244). In his song $\mathrm{Du}$, for example, hexachord-formation can be projected in a number of directions at once (i.e., at the note-for-note attack point level, the registral articulations of linear projections, the voice part alone, the vertical combinations of registral dispersals, and so on), thereby generating a network of associations that is maximally dense. As it is with the conceptual sign under deconstructive pressure, Babbitt's differential musical weave disconcerts our ability to fasten securely onto a fixed musical event. The single tone's Mehrdeutigkeit is its essence:

principles of relatedness, upon which depends immediate coherence of continuity, [...] evolve in the course of the work [rather than being] derived from generalizable assumptions (Babbitt 1978: 246).

And yet the irreducibly propulsive mobility of $D u$ - a scene of wall-to-wall deferral, whereby polyphonic threads actively jostle for syntax-formation - is not deconstructive to the extent that the paths of its many transformations culminate in a pattern that is crafted pre-compositionally. If, as Babbitt's language sometimes implies, the omni-temporalized threads must be "accurately" grasped as "functions" that, however much they have been "multiplied," ultimately secure the "coherent structure" of the compositional whole, then our hearing must rein in the unforeseeable places that overflow and crack that "total structure" (Babbitt 1978: 245). ${ }^{6}$ For

\footnotetext{
6 This argument is an extension of the central argument of Adorno's Philosopby of Modern Music, which consistently associates the twelvetone music of Schoenberg, and especially Webern, with the failure of reified and undialectical thought. Through the rigid application of the rules of the row, Webern's music "designates the liquidation of counterpoint," which, for Adorno, "has the right to exist only in the overcoming of something not absorbed within it, and thus resisting it, to which it is 'added"' (Adorno 1973: 95). In other words, by making the contrapuntal ideal of formal integration absolute, Webern evacuates the recalcitrant subjective dimension that makes this integration dialectically significant. Absolute variation, in short, recapitulates stasis. The difference between Adorno's position and mine is one of emphasis: in my view, the dialectic is only frozen to the extent that it limits itself to the promised structural coherence of the totality; it is not an inevitable consequence of the compositional procedure. In Scherzinger 2004a, for example, I demonstrate, in contrast to Adorno, cases of internally differentiated twelve-tone processes, outlining ways of listening to the music's behavior that does not acknowledge its structural raison d'être.
} 
all its radical temporality under these conditions of listening, the deconstructive other of $D u$ has (paradoxically) been "temporalized" into an economy of the same; the horizon of what is hearable has been pre-planned. Once again, the ethics of contrapuntal weavings, one might say, are not equal.

Derrida's reverential genuflections toward music notwithstanding, we see that music's deconstructive impulse is never assured. Even radical efforts to dissociate music from its preplanned determinations, to sever the assurance of its syntactical teleology in the manner of John Cage, for example, will not in and of itself perform deconstructive work. The aleatorically punctured and displaced hymns by William Billings in Cage's Hyms and Variations (1979) "suddenly brilliant in a new kind of way because each sound vibrates from itself, not from theory" - serve less to defamiliarize than to refamiliarize the hymns' peculiar sensuous resonance. As it is with Barthes's grainy voice, the eighteenth century hymns, recast in this unsettled setting, seem to unleash their interior, non-discursive sonorities. And yet, to the extent that this mode of hearing "the sound itself" - as unmediated engrossment - stops up its ears to the differential structure of our hold on presence, it cannot operate deconstructively. While it may be possible to eliminate traces of its operative syntax, the dissociated tones of Hymns and Variations are all already more than "themselves," acoustically and emotionally permeated by textures of embedded sense (the warm familiarity of the strings, the organic peacefulness of the tempo, and so on, which reassure the subtle process of dislodging). The musical sound itself cannot, to cite Adorno, "rebel [...] against the composer's own established system" (Adorno 1992: 279). Another return, one might say, of the same.

How then can musical thinking set forth deconstructive thought; set forth "on the track," in Derrida's words, "of an impossible axiomatic which remains to be thought" (Derrida 1997: 81)? Under what conditions can music "proliferate outside [of itself] to the point of no longer being understood" (Derrida 1982: xv)? When can it become a "hematographic music," no longer restrained by "prolific avarice obtuse music;" a music "without ram, or age, or ramage, and which has neither tone nor age" (Derrida 1982: xv)? In his reflections on the politics of friendship, Derrida advances as a basis for friendship the insecurity of an empathetic mode of listening. Love in friendship, or "lovence," is possible for Derrida, provided that

you open yourself, trembling, on to the 'perhaps'. [...] That is what can take place, if one thinks with a minimum of coherence the logic of the perbaps. This is, rather what can happen to logic following the experience of the perhaps. That is what may happen to experience, perhaps, and to the concept of experience (Derrida 1997: 69, 70).

Derrida emphasizes the perhaps-structure of an effort to listen to the other, and in so doing also displaces the very modality of hearing at play in such an effort. Deconstruction, in the thought of music, then, is a way of hearing; it is the keen attention paid to a friend. Like Marion Guck's "music loving," deconstructive listening yields "to powers music has to engage and change those who become intensely involved with it;" it is a modality that attempts to hear the "unheard-of" thought in a musical experience, which in turn traces the conditions of its possibility and impossibility (Guck 1995: 1; Derrida 1982: 22). Such a mode of listening is alert to musical features, figures, shapes, events, interactions, affiliations, etc., that fail to line up with the music's most apparent field of operation, and, in so doing, sharpens, and even alters, the very mode that has been put into play. ${ }^{7}$ Deconstruction in music is thus a mode of alertness.

The necessary poetic metaphors - figure, shape, event, etc. - do not apply without preparation; they merely function as a foundational ruse; the faulty foothold that makes possible a musical deconstruction. 
To begin with the tone: Listening to the resonance of the tone on the first beat of the fourth measure in Beethoven's piano sonata, op. 10, no. 3, can be a strange oscillatory experience. ${ }^{8}$ Does this open chord, sparely sounding four octaves of the note A, sound like a tonic or a dominant? Or does it sound like a tonic but function like a dominant - a tonic-sounding dominant? (If so, does the sound weigh upon the function?) The strange neither/nor-yet-both/and resonance of the note comes out of a passage characterized by a short scalar descent in octaves from D to A (m. 1), followed by an arpeggiation of the D major chord (m. 2), and then a short scalar ascent to A (m. 3). A strangely sliding invertible situation; slippery because the octaves on $\mathrm{D}$ and $\mathrm{A}$, clearly sounding as melodic/harmonic pillars in the flow, echo in a shifting rhythm across the tuneful down-and-up. This is to say that $\mathrm{D}$, which first appears on the weak upbeat, appears on two successive strong downbeats; in contrast, A, which first appears on two successive weak downbeats, appears finally on a strong downbeat. ${ }^{9}$ When the music halts on this last beat, it sounds startled, as if interrupted by a rhythmic rule of accent. It is a moment suddenly caught naked, looking askance for its garments. Stranded on an untimely tone (is it belated or premature?), the passage releases a functional phantasm. It is not that the functional context of this tone is itself put into question here; there is no question, that is, that the music is in the ringing clarity of D Major. And yet the specific character of the tone is, strictly speaking, undecidable. The equivocal reverberation of this moment is obviously not an aesthetic flaw; nor can its precise function be said to become clarified by the ensuing music (which continues with a first inversion D Major triad). On the contrary, the undecidability, which issues precisely when the pause invites us to ponder the music on the basis of a tone's presence, conditions the very experiential horizon of the tone. This is the unforeseen shadow dance of the music's Mebrdeutlichkeit.

When the music recalls the opening passage again (in $\mathrm{mm}$. $17 \mathrm{ff}$.) it rides on the very ambiguity of this moment. In this passage, intensified by the offbeat rhythmicization of left and right hand parts, the melody travels right through the above-discussed pause on A, as if to avoid the mixedupness of such pausing, and moves ever-upward, sounding a prominent downbeat on D en route, towards $\mathrm{F}$. Having obliterated all traces of its exposed flirtation with a dominant function, the new pause (on m. 22) seems to emit a less ambiguous sound: the robust delivery of the tonic's third degree; a full fortissimo blow intoned in a measured tempo rubato. And yet, as if to yield, against odds, to the lingering double-meaning of arrested melodic movement, the F\# too functions as both tonic and dominant - the third degree of tonic in D Major, that is, and the first degree of dominant in B Minor (in which key the music continues on its way). Arguably, the already-sounded chromatic A\# serves to prepare the tonicization of B Minor to follow, which in turn grants $\mathrm{F} \#$ its new operative ambiguity between tonic and dominant. But the earlier appearance of the chromatic A\# (m. 13) served, harmonically speaking, to craft the cadence that ultimately reinforced the key of $\mathrm{D}$ major; while the second appearance of the chromatic A\# served, rhythmically speaking, to reinforce the arrival of D on the downbeat of m. 21. As it was with A, F\#s new double meaning is unawaited. So once again, the music's second pause on a single unadorned tone opens into the oblique reverberations of unanticipated doubleness. These pauses (which, aside from the literal repetition in the recapitulation, do not recur until the pause placed on the last silence closing the movement) are a summons to listen, within the music's internal temporalities, to a diversity whose resonance cannot be foreheard.

8 I would like to thank Joseph Dubiel for inviting me to consider the paradoxes of this musical moment.

Beethoven draws attention to these shifting points of melodic/harmonic emphasis by (1) beginning the music on the note $\mathrm{D}$; and also by (2) placing the ensuing D's on respective downbeats (in $\mathrm{mm} .2$ and 3); and by (3) allowing A to register the boundaries of the melodic enclosure (the low point in $\mathrm{m}$. 1 and the high point in $\mathrm{m}$. 4), and also (4) beginning an additional layer of octave doubling on A in midmeasure (in m. 2). 
It is clear of course that the peculiar resonance of Beethoven's A, no less than his F\#, is heard within the context of a common practice system of functional tonality. However, far from simply shoehorning our hearing into the pre-given convention that guides it, deconstructive listening, situated within a deliberately framed and impossible present, operates at a remove from the music's normative behavior. By marking moments that fail to be fully reclaimed by their generalized traditional sense, the music issues a warning against the dubiousness of its own second-nature. It opens the horizon of what is hearable in the music of that tradition. This does not mean that the deconstructive resonance of a musical tone, or a musical sonority, necessarily fluctuates against a fixed tradition. Deconstructive listening, one might say, marks the undecidability of what goes as tradition, casting perspectives thereby onto its very conditioning grounds. Tradition, one might say, opens into hesitation.

The contradictory resonance of the sonority that lingers at the end of Helmut Lachenmann's ein kinderspiel, for solo piano (1980) dramatizes, in a very different tonal context for example, this tradition-disconcerting (deconstructive) mode of attention. The final movement, as if to encourage such a mode, is revealingly titled Schattentanz. At first, the music sounds like a minimalist elaboration of an unchanging half-tone dyad (C/B, in the piano's highest register) in the context of a child-like rhythmic dance. Two basic rhythmic figures appear throughout: a typical long-short gigue figure and a dotted-note figure whose initial long-short pattern can be heard as a kind of diminution of the gigue figure. The overall rhythmic pattern of m.1, presenting the gigue figure for three beats followed by the dotted figure for one beat, is itself a kind of augmentation of the long-short motif; it becomes a characteristic macro-rhythm defining the overall flow. The two basic rhythmic figures reduce to a single note value (sometimes a quarter, sometimes a dotted quarter) at three places in the movement (mm. 25-30; 61-68; 82ff.). As it might be with an eighteenth-century gigue, the music's measures are initially patterned into simple groupings that, while never quite predictable, constellate into measure units of two, four, eight, sixteen, and so on. Internal differentiation between groupings is provided by the distributions of characteristic figures, changes in dynamics and adjustments in resonance created by the pedal as well as by silently depressed keys on an octave A in the low bass.

In this way, arrangements of metric/rhythmic emphasis shift throughout the piece. In the opening measures, for example, the grand crescendo and the dotted figure discharge a firstbeat accentuation (the absence of a crescendo in $\mathrm{m} .5$ is offset by the inclusion of a dotted figure in m.6); while in $\mathrm{mm}$. 9-10 the accent shifts to the second and fourth beats (emphasized by the depressed pedal on these beats), neither of which assumes strict hierarchic precedence. It is in this newly aligned period of beating that something uncanny materializes: the stratospheric cluster suddenly shades over with the mysterious designs of heterogeneous percussion. We hear in the innards of the seemingly familiar sonority a deep and unimaginable echo; it has not yet emerged but it is no longer submerged - like the haunting apparition of a colossal army on the march. This is a minimalist gigue becoming a march of the multitude. What is happening? The sound is becoming other; it is beginning, in Derrida's lexicon, "to tympanize" - musically, to "relate $[\ldots]$ to something to which it has no relation;" it is ceding to "hematographic music," uncovering a looming presence hidden in the shadow-dance (Derrida 1982: x, xiv, xv).

When the apparition recedes (on the second beat of $\mathrm{m}$. 13?), the dotted-note figure of the music's first rhythmic pattern seems to arrive too early. Seduced by the looming left-right-leftright that we strain to resist, our sense of temporal proportion has been bewitched; a beat has been forgotten. Shortly after this, the dotted figure seems to arrive too late because the giguelike beating begins, as an upbeat, early ( $\mathrm{mm}$. 20-21). (Did we find the lost beat?) These passages oscillate precariously between the two fields of accentuation presented thus far (first beat 
accentuations in mm. 13-16 and 21-24; and second and fourth beat accentuations in mm. 1720 and 25-30). It is in this last passage that the dance figures have whittled down into single notes, and the compound-time gigue steps fully yield into and become grim marching. It is as if the march, which once loomed in the shadows, has now subjugated the dance. The shock of this moment lies in the way the shadow-timbres begin to loom large over the cluster. Viscerally overwhelming the descant dance-fragment - now whimpering, abbreviated and naive - the shadow resonance comes alive with the booming insecurity of wavering resonance. Each inexorable boom is inflected by a hitherto unimagined multiplicity. There is drumming in the depths and tapping in the heights, there are dispersals of overtone coloration, declensions of micro-mingling echoes, peripheral sounds, residual sounds, chimera. The massive march reverberates: mebrdeutig.

This indirect experience, not evident when we first encountered the sonority in itself and also weirdly de-linked from the direct motor actions of the pianist, is the uncanny excess that comes into earshot deconstructively. This resonance is the missing piece/the extra piece that was aurally present all along; it is the necessary accessory that menaces the security of our hearing the descant in itself. After the piece makes a turn through another metric displacement, this time bringing emphasis to the third beat ( $\mathrm{mm} .22-40)$, we find the pianist's resonance-producing techniques themselves displaced. Here two parallel two-measure groups insinuate a different quality of echo; in the first ( $\mathrm{mm}$. 41-42 and $\mathrm{mm}$. 45-46) the crescendo is spatially expanded by the left pedal, in the second ( $\mathrm{mm} .43-44$ and 47-48) the crescendo is spatially expanded by the middle pedal (with the low octave on A silently depressed). A distinction between the hitherto, albeit wavering, equivalent-seeming resonance effects comes unexpectedly to the ear; a contrast that is particularly pronounced in the isolated attacks on the second beats of measures 61-68, which exchange left and middle pedals. The inner recesses of the sound, it turns out, has an oscillating residue; its qualities differentiate. At the end of the movement, the displacement of resonance from source becomes absolute. The final tones are produced by the pedal alone, which is lifted and depressed ("marcato possible") in march-like time. From these foot movements emanate the residue of sounds still swirling in the rattled belly of the piano. Weirdly, the noise of the pedal release booms gulpingly (like some phantom dominant) below the ever-clearing tonal resonance. Down-up, down-up, short-long, short-long (it goes): the long-short-ishness of the music has finally become a short-long. Has the dancing finger-music finally become the footwork of a march?

By listening to the music as an apparitional transformation from its self-present sounding (as gigue, as pitch cluster) into an entirely alien soundscape (as march, as ghostly cry) marks the differential structure of our hold on the music's self-presence. In Adorno's terms, one might say, this is the "more" that art appears to be saying:

To wrest this more from that more's contingency, to gain control of its semblance, to determine it as semblance as well as to negate it as unreal: This is the idea of art (Adorno 1997: 78).

In Derrida's terms, one might say, the music has yielded to its intimate alterity, "the irreducibility of the aftereffect, the delay" (Derrida 1982: 21). As it is with deconstruction, the music's "metaphysical drumming" unleashes the oblique resonance of the tympanum; it "repercusses its [...] limit [...] in sonorous representation;" "attempts to think th[e] unheard-of thought" (Derrida 1982: xiii, xix, 22). Deconstruction, in music, then operates on the basis of a musical detail, figure, shape, event - to the extent that such a nominal accretion can be isolated and spoken about - that unexpectedly exceeds itself, reaching out and becoming something other than what it 
takes itself to be. It begins to relate to something to which it has no immediately apparent relation, and which no theory will have been prepared to conform or translate in advance.

\title{
5. Idealization to a Prelude
}

\author{
The aim of every artistic utopia today is to make \\ things of which \\ we do not know what they are. \\ (Adorno 1992: 322)
}

Deconstruction, then, is an act of close listening, a modality that seeks to open the horizon of differential traces lingering in the music's internal temporalities. It does not offer a theory of music; nor even an analysis of the music under consideration. Deconstruction is en route to a theoretical beginning; an idealization to a prelude. It does not "apply" to some music better than to other music; nor does it only operate on the mechanism of resonance (as in my two examples above). It is true that some recent music takes as its task the very dramatization of the deconstructive mode of hearing. The strangely resounding difference tones (tones of difference?) in “Louis Andriessen's ironic Ende (1981), for 2 alto recorders (1 player), for example, explore resonance-effects that disfigure the naïve hold we have on the music's initial presence. Or, the chimerical tempo fluctuations in György Ligeti's first etude for piano, Désordre (1985), explore inherent patterns that emerge like illusions in a granulated continuum. And so on. It is even possible today to identify an assemblage of compositional thought that consciously articulates with a relentlessly critical or deconstructive mode. For Wolfgang Rihm, whose engagement with Adorno is well-known, for example, the musical work is driven by a quest for its internal "Other," which in turns opens into a presentiment of utopian freedom. Ligeti too claims to have successfully realized Adorno's negatively utopian "musique informelle" in his 1963 work Atmosphères (see Adorno 1992: 269-322). The list of self-professed deconstructive music is long.

But such aspirations notwithstanding, deconstruction is not associated with a musical genre as such. As Derrida tirelessly points out, there is a history and a tradition of deconstruction, "from Luther to Heidegger (Luther was already speaking of Destruktion to refer to a sort of critique of institutional theology in the name of the original authenticity of the evangelical message)" (Derrida 2005: 115). Deconstruction is less a postmodern characteristic of music and more a precarious exegesis of music's embedded enigmas. In Derrida's words, "It's what comes along [arrive: happens];" "It is the possibility of the impossible" (Derrida 2005: 114). Some recent music theory, albeit apparently unaware of its allegiance, in fact defines music's unique character in terms that betray a general affinity with deconstruction. David Lewin, for example, has defined musical ideas in terms of a dense transformational logic, whereby every musical event, down to the bare musical interval, is an internally differentiated trace of a radically temporalized phenomenological situation. (For a fuller discussion of the affinities between Lewin and Derrida, see Scherzinger 2004.) In Lewin's lexicon, the musical experience is an omni-temporalized text, which, like dissemination, produces boundless semantic effects, and thus disconcerts the desire to pin down an exhaustive checklist of its signifieds. Music, it seems, illuminates deconstructive thought.

When Lewin analyzes Franz Schubert's song Morgengruß from Die Schöne Müllerin, for example, he strategically frames a perception of the contents of $\mathrm{m} .12$ as if they could be spatialized on the basis of a self-evident positivity (Lewin 1986). Listening closely to this impossi- 
ble presence disseminates into multiple temporal horizons that make possible the perception. In Derrida's scheme, dissemination/différance interrupts any identity of a term or concept to itself, or any homogeneity of a term/concept within itself. By marking the detour/supplement through which a concept comes to meaningfulness, différance submerges the concept in a signifying chain that lies beyond the immediate context of that concept. The concept is thus no longer only itself in itself. It becomes a conceptual effect, a nominal accretion produced by a complex interweaving of signifiers: a concept-metaphor. Irreducibly temporalized, then, the contents of $\mathrm{m} .12$ become non-identical transformations with no stable referent. For example, the sound is at once a kind of blues-inflected V chord (a leading-note-less dominant sensation), a propulsive sequence on the way to $\mathrm{D}$ Minor (a functional predominant), an aspect of a move towards C Minor (a descending chromatic journey through flattened seventh and sixth degrees), a decorative inmate of a large-scale dominant prolongation in C Major (an upper neighbor to the neighboring A-flat that prominently colors the music's basic progressions), and so on. None of these inflections, contradictory as they are, fully cancel out any other; the perceptual adjustments of attitude precisely put into play the aesthetic content of the music. There is no essence of m.12. Like différance, "it (is) that which not only could never be appropriated in the as such of its name or its appearing, but also that which threatens the authority of the as such in general, of the presence of the thing itself in its essence" (Derrida 1982: 26).

Likewise, when Joseph Dubiel analyzes the first movement of Mozart's piano sonata, K. 331, . he strategically frames a perception of the inner pedal tone $\mathrm{E}$ as if it could be isolated as a naïve positivity (Dubiel 2006). Close attention to its persistent presence deconstructively transforms the very identity of its apparent immobility. For Dubiel, ontological complications precisely derive from the changing musical attributions we can grant $\mathrm{E}$ in its shifting sonorous context. Its innocuous first appearance as a harmonizing inner voice (unresponsive to the melodic moves of the surrounding parallel tenths), that is, transforms in the context of m. 2. This is not a metamorphosis based on the truism that all and any repetition is change. In m. 2, E has come, at once, to be more peripheral from the surrounding sonority (unflinching in the context of melodic dancing), and more central (providing the root for dominant harmony) than it was before. The odd second inversion constellation, a fourth plus a minor seventh (B3, E4, D5), produced on the second half of $\mathrm{m} .2$ begins, inaudibly almost, to divide the two halves of an apparently parallel measure. In $\mathrm{m} .3$, this odd constellation appears again, this time a minor seventh plus a fourth (F\#3, E4, A4), made odder still by the fact that it cannot be easily assimilated into an idiomatic chord. For Dubiel, the very oddness "draws out for us the less obtrusive oddness of the preceding $\{\mathrm{B} 3, \mathrm{E} 4, \mathrm{D} 5\}$, the two joining in a kind of private communication at a remove from the music's normative triads:" another Schattentanz that flashes up and vanishes in the disseminating resonance of Mozart's music (Dubiel 2006: 9).

It is not only that the flux constitutes the paradoxical ontological creation of the tone of our listening, but that the theory itself shifts under the sway of such listening. The grammar of the pedal point, its stasis apparently producing dissonance against shifting normative harmonies, is menaced thereby. Dubiel's analysis, that is to say, poses the question: Is the E4 dissonant against the melodic $\mathrm{F} \#$ ? Or is the $\mathrm{F} \#$ suddenly dissonant against $i ?^{10}$ Once again, this musical moment suddenly encounters one of its horizons of undecidability. In the words of Derrida,

It erases itself in presenting itself, muffles itself in resonating, like the a writing itself, inscribing its pyramid in différance (Derrida 1982: 23).

\footnotetext{
10 It is as if $\mathrm{F} \#$ can no longer be relied upon as leading the musical action. As it was with the B3 in m.2, which did not resolve felicitously, $\mathrm{F} \# \mathrm{~S}$ (melodic) independence is called to question.
} 
As to the identity of the pedal point, then, one might ask: "Is it nameable, that which it is wearing itself out trying to name?" (Derrida 1997: 71).

There will be no unique name, even if it were the name of Being. And we must think this without nostalgia, that is, outside of the myth of a purely maternal or paternal language, a lost native country of thought. On the contrary, we must affirm this, in the sense in which Nietzsche puts affirmation into play, in a certain laughter and a certain step of the dance. (Derrida 1982: 27)

To dance in music's shadows: Mozart's ephemeral other-tongue, Beethoven's unanticipated resonance, Schubert's contradictory criteria, Andriessen's disfiguration, Ligeti's acoustic illusion, Lachenmann's dispersal. These are the preludes to an ideal over which no system can gain complete control. The squinting tympanum: to listen to things of which we do not know what they are.

\section{Bibliography}

Adorno, Theodor W. (1973). Philosophy of Modern Music. New York: Seabury Press.

Adorno, Theodor W. (1992). Quasi Una Fantasia. London and New York: Verso.

Adorno, Theodor W. (1997). Aesthetic Theory. Minneapolis: University of Minnesota Press.

Babbitt, Milton (1978). 'Who Cares if You Listen'. In: . Schwarz, Elliott / Childs, Barney (eds.). Contemporary Composers on Contemporary Music. New York: Da Capo.

Barthes, Roland (1985). 'The Grain of the Voice'. In: The Responsibility of Forms: Critical Essays on Music, Art, and Representation. New York: Hill and Wang, 267-77

Bond, Mark Evans (1997). 'Idealism and the Aesthetic of Instrumental Music at the Turn of the Nineteenth Century'. In: Journal of the American Musicological Society 50/2-3, 387-420.

Derrida, Jacques (1976). Of Grammatology. Baltimore, MD: Johns Hopkins University Press.

Derrida, Jacques (1982). Margins of Philosophy. Chicago: University of Chicago Press.

Derrida, Jacques (1995). Points: Interviews 1974-1994. Stanford: Stanford University Press.

Derrida, Jacques (1997). Politics of Friendship. London and New York: Verso.

Derrida, Jacques (2005). Paper Machine. Stanford: Stanford University Press.

Dubiel, Joseph (2006). 'Theory as Text and as Mindset: Some Observations (for Benjamin Boretz at seventy)'. In: Perspectives of New Music, Vol. 43, No. 2. Forthcoming.

Eagleton, Terry (1983). Literary Theory: An Introduction. Oxford: Blackwell.

Foucault, Michel (1973). The Order of Things: An Archaeology of the Human Sciences. New York: Vintage.

Guck, Marion. 'Music Loving, Or the Relationship with the Piece'. In: Music Theory Online, Volume $2.2 \mathrm{O}$

Huray, Peter le / Day, James (1988). Music and Aesthetics in the Eighteenth and EarlyNineteenth Centuries. Cambridge: Cambridge U.P.

Kant, Immanuel 1951. Critique of Judgment. New York: Hafner Press.

Korsyn, Kevin (2003). Decentering Music: A Critique of Contemporary Musical Research. New York: Oxford University Press.

Laclau, Ėnesto (1996). 'Deconstruction, Pragmatism, Hegemony'. In: Mouffe, Chantalle (ed.). Deconstruction and Pragmatism. London and New York: Routledge, 47-67.

Lewin, David (1986). 'Music Theory, Phenomenology, and Modes of Perception'. In: Music Perception, Vol. 3, No. 4, Summer, 327-392. 
Man, Paul de (1983). Blindness and Insight: Essays in the Rhetoric of Contemporary Criticism. Minneapolis: University of Minnesota Press.

Nietzsche, Friedrich Wilhelm (1967). The Birth of Tragedy. New York: Vintage Books.

Nietzsche, Friedrich Wilhelm (1974). The Gay Science (with a Prelude in Rhymes and an Appendix in Songs). New York: Vintage Books

Nietzsche, Friedrich Wilhelm (1980). On the Advantage and Disadvantage of History for Life. Indianapolis and Cambridge: Hackett Publishing Company.

Nietzsche, Friedrich Wilhelm (1980a). 'On Words and Music'. In: Carl Dahlhaus, Between Romanticism and Modernism: Four Studies in the Music of the Later Nineteenth Century. Berkeley, Los Angeles and London: University of California Press, 103-119

Nietzsche, Friedrich Wilhelm (1989). On the Genealogy of Morals and Ecce Homo. New York: Vintage Books.

Pressnitzer, Daniel / McAdams, Stephen (2004). 'The Return of the Aesthetic: Musical Formalism and Its Place in Political Critique'. In: Dell'Antonio, Andrew (ed.). Beyond Structural Listening? Postmodern Modes of Hearing. Berkeley and Los Angeles: University of California Press, 252-277.

Pressnitzer, Daniel / McAdams, Stephen (2005). 'Acoustics, Psychoacoustics, and Spectral Music'. On: . Accessed on December 2005.

Scherzinger, Martin (2004). 'The Return of the Aesthetic: Musical Formalism and Its Place in Political Critique', In Dell'Antonio, Andrew (ed.). Beyond Structural Listening? Postmodern Modes of Hearing. Berkeley and Los Angeles: University of California Press, 252-277.

Scherzinger, Martin (2004a). 'In Memory of a Receding Dialectic: Notes on the Political Relevance of Autonomy and Formalism in Modernist Musical Aesthetics'. In: Ashby, Arved (ed.). The Pleasure of Modernist Music, Rochester: University of Rochester Press, 68-100.

Schopenhauer, Arthur (1958). The World as Will and Representation. Indian Hills, Colo.: Falcon's Wing Press. 